\title{
Quercetin sebagai Penghambat Aktivasi NF-K $\beta$ dan Penurunan Kadar MCP-1 pada Kultur HUVECs yang Dipapar dengan Leptin
}

\section{Quercetin as NF-KB activation inhibition \& MCP-1 level decreasing on HUVECs culture exposed by Leptin}

\author{
Muhammad Masyhur ${ }^{1}$, Kusworini Handono ${ }^{2}$, L Enggar Fitri ${ }^{3}$, M Rasjad Indra ${ }^{4}$ \\ ${ }^{1}$ Sekolah Tinggi Ilmu Kesehatan Pemkab Jombang \\ ${ }^{2}$ Laboratorium Patologi Klinik Rumah Sakit Dr. Saiful Anwar \\ ${ }^{3}$ Laboratorium Parasitologi Fakultas Kedokteran Universitas Brawijaya \\ ${ }^{4}$ Laboratorium IImu Faal Fakultas Kedokteran Universitas Brawijaya
}

\begin{abstract}
ABSTRAK
Hiperleptin mempengaruhi proses oksidasi enzim $N$-acetyldiphosphat (NADPH) yang berfungsi pada proses metabolisme dan reaksi redoks sehingga terjadi stres oksidatif. Peningkatan ROS menyebabkan aktifnya nuclear factor kappa beta (NF$\kappa \beta$ ) yang mengubah reaksi redoks di dalam sel melalui dimer p50 dan p65 yang bertranslokasi ke inti sel yang akan mempengaruhi gen promoter untuk mengekspresikan faktor kemotaksis yaitu monocyte chemoattractant protein-1 (MCP-1). Tujuan penelitian ini adalah melihat efektifitas quercetin pada penurunan ekspresi protein proinflamasi penyebab aterosklerosis. Penelitian ini merupakan eksperimental murni dengan menggunakan sampel kultur sel endotel manusia (HUVECs) yang diberi leptin $500 \mathrm{ug} / \mathrm{mL}$ dan diinkubasi selama 6 jam yang selanjutnya diberi perlakuan quercetin dengan variasi dosis $0 \mu \mathrm{M}, 50 \mu \mathrm{M}, 125 \mu \mathrm{M}$ dan $625 \mu \mathrm{M}$ dan diamati aktivasi NF-k $\beta$ menggunakan metode immunofluorescence dan kadar MCP-1 menggunakan teknik ELISA. Hasil analisa data dengan menggunakan Tukey menunjukan adanya penurunan aktivasi NF- $\beta \beta$ yang signifikan setelah diinkubasi dengan quercetin dosis $125 \mu \mathrm{M}$ $(p<0,001)$ dan penurunan kadar MCP-1 sebesar 503,40 $\pm 23,93324(p<0,001)$ apabila dibandingkan dengan kontrol positif. Dosis optimal quercetin adalah perlakuan dengan dosis $125 \mu \mathrm{M}$ karena memberikan pengaruh yang signifikan dalam menurunkan kadar MCP-1 dan penghambatan aktivasi NF-k $\beta$. Dosis $625 \mu \mathrm{M}$ hanya menghambat aktivasi NF-k $\beta$ tetapi tidak signifikan dalam menurunkan kadar MCP-1 $(p=0,916)$. Peningkatan dosis quercetin menunjukkan korelasi yang signifikan dengan penurunan kadar MCP-1 $(r=-0,498, p<0,001)$ dan penghambatan aktivasi NF- $\beta(r=-0,803, p<0,001)$.
\end{abstract}

Kata Kunci: Aktivasi NF-k $\beta$, disfungsi endotel, leptin, MCP-1, quercetin

\begin{abstract}
Hyperleptin affecting oxidation process of $\mathrm{N}$-acetyldiphosphat (NADPH) enzyme which functioned in the metabolic process and redox reaction, resulting oxidative stress. ROS increasing trigger the activation of nuclear factor kappa beta (NF-KB) which alters redox reaction in the cell through translocation of $p 50$ and $p 65$ dimer to the cell nuclear affecting promoter gen to express chemo taxis factor, monocyte chemoattractant protein-1 (MCP-1). The research aims to observe the quercetin effectiveness on pro-inflammation protein expression decreasing caused atherosclerosis. This is an experimental laboratory experiment using human endothelia cell sample (HUVECS) exposed by Leptin 500ug/mL and incubated for 6 hours then treated with quercetin with dose variation of $0 \mu \mathrm{M}, 50 \mu \mathrm{M}, 125 \mu \mathrm{M}$ and $625 \mu \mathrm{M}$. The NF- $\kappa B$ activation observed with immune-fluorescence method and MCP-1 level measurement used ELISA technique. Data analysis using Tukey showed the significant decreasing of NF-KB activation after incubated with quercetin $125 \mu M(p<0,001)$ and decreasing

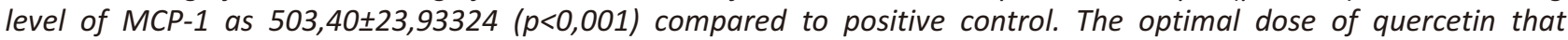
significantly decreases MCP-1 level and NF-KB activation inhibition is $125 \mu \mathrm{M}$. Meanwhile, quercetin dose of $625 \mu \mathrm{M}$ only inhibiting NF-KB activation but not significantly decreasing the MCP-1 level $(p=0,916)$. The increasing of Quercetin dose showed a significant correlation with the MCP-1 level decreasing $(r=-0,498, p<0,001)$ and NF- $\kappa 8$ activation inhibition ( $r=-$ $0,803, p<0,001)$.
\end{abstract}

Keywords: Endothelial dysfunction, leptin, MCP-1, NF-KB activation, quercetin

Jurnal Kedokteran Brawijaya, Vol. 26, No 4, Agustus 2011; Korespondensi: Muhammad Masyhur. Sekolah Tinggi Ilmu Kesehatan Pemkab Jombang, Jl. dr. Soetomo No. 75-77Jombang Tel. (0321)870214 Email: kond4ng@gmail.com. 


\section{PENDAHULUAN}

Prevalensi overweight dan obesitas meningkat sangat tajam di seluruh dunia yang mencapai tingkatan yang membahayakan. Kejadian obesitas yang ada di negaranegara maju seperti di negara-negara Eropa, USA dan Australia telah mencapai tingkatan epidemi. Keadaan tersebut tidak hanya terjadi di negara-negara maju. Di beberapa negara berkembang obesitas justru telah menjadi masalah kesehatan yang lebih serius. Sebagai contoh, $70 \%$ penduduk dewasa Polynesia di Samua sudah mengalami obes $(1,2)$.

Obesitas merupakan akibat dari adanya ketidakseimbangan antara energy intake (asupan energi) yang melebihi energi yang digunakan (energy expenditure). Beberapa mekanisme fisiologis berperan penting dalam diri individu untuk menyeimbangkan keseluruhan asupan energi dengan keseluruhan energi yang digunakan dan untuk menjaga berat badan stabil dalam jangka waktu yang cukup panjang. Obesitas hanya akan muncul apabila terjadi ketidakseimbangan energi untuk periode waktu yang cukup panjang (2).

Pada keadaan obesitas terjadi resistensi leptin di hipotalamus sehingga menyebabkan gangguan transport leptin melalui blood brain barrier dan adanya gangguan dari supresor of cytokine signalling (SOCS). Perubahan keadaan ini menyebabkan peningkatan konsentrasi leptin di plasma darah pada penderita obesitas yang disebut hiperleptinemia (3). Hiperleptinemia merupakan salah satu ciri dari obesitas dan keadaan ini mempengaruhi proses oksidasi enzim $\mathrm{N}$-acetyldiphosphat (NADPH) yang berfungsi pada proses metabolisisme dan reaksi redoks, peningkatan radikal hidroksida $\left(\mathrm{OH}^{*}\right)$, superoksid $\left(\mathrm{O}^{*}\right)$, dan hidrogen peroksida $\left(\mathrm{H}_{2} \mathrm{O}_{2}\right)$ baik secara in-vitro maupun in vivo. Senyawa-senyawa ini menyebabkan terjadinya peningkatan stres oksidatif di endotel yang akhirnya terjadi akumulasi radikal bebas dalam hal ini Reactive Oxigen Species (ROS) (4).

Ikatan leptin dengan reseptor leptin (obR) menyebabkan timbulnya akumulasi ROS yang berakibat pembentukan radikal bebas superoksida dan selanjutnya NF-k $\beta$ mengalami aktivasi. Aktifnya NF-k $\beta$ dapat menginduksi terbentuknya protein-protein sistem imun seperti sitokin meliputi tumor necrosis factor- $\alpha$ (TNF- $\alpha$ ) dan Interleukin-1 (IL-1), molekul adesi yang meliputi VCAM dan ICAM-1, zat vasoaktif meliputi eNOS dan NO serta faktor kemotaksis seperti MCP-1. Kejadian tersebut meningkatkan progresifitas aterosklerosis sehingga mengakibatkan pembuntuan arteri koroner.

Karena inflamasi menjadi faktor utama dari patogenitas aterosklerosis, maka pencegahan dan pengobatan dapat dimulai dengan penghambatan aktivasi protein yang menimbulkan inflamasi, yaitu NF-k $\beta$ sebagai target $(5,6,7)$. Pengobatan yang sering dilakukan untuk menghambat proses aterogenesis bermacam-macam, seperti penggunaan statin dan ACE inhibitor. Salah satu bahan yang dapat mencegah terjadinya aterosklerosis adalah antioksidan, alkaloida, flavonoid seperti halnya quercetin dan mengontrol pola makan dengan banyak mengkonsumsi sayur dan buah. (8). Quercetin merupakan senyawa aktif yang banyak dihasilkan dari buah-buahan misalnya apel, tomat, anggur merah dan juga dari sayursayuran seperti buncis, cabe dan bawang. Quercetin dinyatakan paling banyak didapatkan pada bawang (347 $\mathrm{mg} / \mathrm{Kg}$ ), apel (36 mg/Kg) dan anggur merah (11 mg/Kg). Quercetin termasuk kedalam famili flavonoid yang selama ini diketahui mempunyai efek pada penurunan beberapa ekspresi protein proinflamasi (9).

Penelitian ini dilakukan untuk membuktikan pengaruh pemberian quercetin pada kultur sel endotel (HUVECs) normal dan kultur sel endotel yang telah dipapar dengan leptin terhadap aktivasi NF-k $\beta$ dan kadar Monocyte Chemoattractant Protein-1 (MCP-1). Hipotesis yang ingin diuji adalah apakah pemberian quercetin dapat menghambat aktivasi nuclear factor kappa beta (NF-k $\beta$ ) dan menurunkan kadar monocyte chemoattractant protein-1 (MCP-1) akibat paparan hiperleptin pada kultur sel human umbilical vein endothelial cells (HUVECs).

\section{METODE}

Penelitian dilakukan menggunakan desain eksperimental laboratorium dengan rancangan postest only control group design pada kultur human umbilical vein endothelial cells (HUVECs) yang diinduksi dengan paparan hiperleptin (500ng/mL). Kultur HUVECs dibagi dalam dua kelompok kontrol, yaitu kelompok tanpa paparan quercetin dan leptin sebagai kontrol negatif, kelompok dengan paparan leptin 500 dengan plasebo sebagai kontrol positif, dan 3 perlakuan dan 3 kelompok perlakuan yang diberikan paparan leptim $500 \mu \mathrm{g} / \mathrm{ml}$ dengan tiga dosis leptin yaitu $50 \mu \mathrm{M}, 125 \mu \mathrm{M}$ dan $625 \mu \mathrm{M}$ berdasarkan hasil penelitian pendahuluan. Semua kelompok kultur sel diinkubasi selama 24 jam pada suhu $37^{\circ} \mathrm{C}$ untuk kemudian dilakukan pengukuran aktivasi NF-K $\beta$ dan MCP. Pengukuran ikatan p50-p65 (dimer NF-k $\beta$ ) dilakukan dengan metode immunofluorescence. Kultur sel yang telah siap (monolayer) selanjutnya difiksasi dengan menggunakan methanol $4 \%$ dan selanjutnya dicuci dengan PBS-T 0,1\% 3x masing-masing selama 3 menit, ditambahkan Triton- $X$ 0,2\% pada ice-cold dan diinkubasi selama 5 menit selanjutnya dicuci kembali dengan Phosphate Buffered Saline with Tween (PBS-T) 0,1\% 3x masing-masing selama 3 menit. Blocking dengan BSA dilakukan selama 30 menit dan kemudian dicuci dengan PBS-T 0,1\% 3x masing-masing selama 3 menit selanjutnya menambahkan anti p50 (antibodi primer) dalam blocking selama semalam (overnight). Setelah itu dicuci kembali dengan PBS-T 0,1\% $3 x$ masing-masing selama 3 menit, kemudian ditambahkan antibodi sekunder Fluorescent isothiocyanate (FITC) dan diinkubasi gelap selama 2 jam dalam kondisi dingin dan dicuci dengan PBS-T 0,1\% $3 x$ masing-masing selama 3 menit selanjutnya coverslip diambil dan siap dibaca. Pembacaan dilakukan menggunakan Confocal Scanning Laser Mycroscope (CSLM) pada perbesaran 600x dan perhitungannya dilakukan dengan Immunofluorescence Imaging software.

Pemeriksaan kadar MCP-1 dilakukan dengan menggunakan metode ELISA. Supernatan dari kultur umbilikus ditempelkan kedalam dinding plate Elisa dan diinkubasi semalam (overnight), selanjutnya dicuci dengan PBS-T sebanyak $6 x$ selama 3 menit kemudian ditambahkan $50 \mu \mathrm{l}$ rabbit polyclonal to MCP-1 dalam assay buffer diinkubasi selama 2 jam pada suhu kamar dan dishaker selama 5 menit sediaan dicuci dengan PBST sebanyak $6 x$ selama 3 menit dan ditambahkan $50 \mu \mathrm{l}$ goat Ig G biotin anti rabbit dalam assy buffer diinkubasi selama 1 jam dan dishaker selama 5 menit kemudian dicuci dengan PBS-T 
sebanyak $6 x$ selama 3 menit selanjutnya ditambah $50 \mu l$ SAHRP dalam assay buffer dan dicuci dengan PBS-T sebanyak $6 \mathrm{x}$ selama 3 menit kemudian ditambah substrat Toluen Metiline Blue (TMB) $100 \mu \mathrm{l}$ diinkubasi selama 10 menit pada suhu kamar dan dishaker selama 5 menit. Pada sediaan kemudian ditambahkan $100 \mu \mathrm{HCL} 1 \mathrm{~N}$ (stop solution) kemudian siap dibaca dengan ELISA reader $\lambda$ $450 \mathrm{~nm}$. Untuk mengetahui standar pemeriksaan, data yang telah diperoleh selanjutnya dihitung dengan menggunakan grafik nilai absorbansi sebagai komparasinya

Untuk membuktikan adanya hubungan antara aktivasi NFк $\beta$ dan kadar MCP-1 dilakukan uji regresi korelasi. Perbedaan antara kelompok kontrol dan perlakuan diuji dengan menggunakan uji Analysis of Varians (ANOVA), kemudian dilanjutkan dengan uji Tukey menggunakan SPSS 14 untuk mengetahui kelompok mana yang berbeda secara bermakna.

\section{HASIL}

Ekspresi Nuclear Factor Kappa Betha (NF-KB) dengan metode Immunofluorescence

Ekspresi yang mengindikasikan adanya aktivasi NF-k $\beta$ pada kultur HUVECs yang dipapar quercetin dengan dosis $625 \mu \mathrm{M}(7567,80 \pm 449,96689)$ lebih rendah secara signifikan $(p<0,001)$ dibandingkan kelompok dengan dosis $125 \mu \mathrm{M} \quad(13996,60 \pm 1651,18785)$ dan $50 \mu \mathrm{M}$ $(24727,40 \pm 2755,24859, \quad p<0,001)$ dan kontrol positif $(p<0,001)$. Hasil juga menunjukkan bahwa semakin besar dosis quercetin semakin rendah aktivasi NF-k $\beta$ (Tabel 1).

Tabel 1. Hasil analisis Tukey jumlah NF-k $\beta$ yang teraktivasi pada sel endotel

\begin{tabular}{ll}
\hline \multicolumn{1}{c}{ Perlakuan } & \multicolumn{1}{c}{$\begin{array}{c}\text { Aktivasi NF-kB (\%) } \\
\text { Mean } \pm \text { SD* }\end{array}$} \\
\hline Kontrol & $1490,20 \pm 115,15945^{\mathrm{a}}$ \\
Kontrol Leptin & $36096,60 \pm 144,99241^{\mathrm{e}}$ \\
L500 Q50 & $24727,40 \pm 2755,24859^{\mathrm{d}}$ \\
L500 Q125 & $13996,60 \pm 1651,18785^{\mathrm{c}}$ \\
L500 Q625 & $7567,80 \pm 449,96689^{\mathrm{b}}$
\end{tabular}

Keterangan : ${ }^{*}$ ) Notasi yang berbeda menunjukkan perbedaan yang signifikan $(p<0,05)$

Kadar Monocyte Chemoattractant Protein-1 (MCP-1) dengan Metode ELISA

Hasil menunjukkan bahwa kadar MCP-1 pada pemberian leptin $(656,00 \pm 73,42683)$ lebih tinggi secara bermakna dibandingkan normal $(504,80 \pm 16,75410)$. Pemberian quercetion pada dosis 50 memberikan kadar MCP-1 $(574,40 \pm 43,72414)$ yang lebih rendah daripada kontrol positif hingga sama dengan normal $(p=0,04)$. Peningkatan quercetin hingga 125 memberikan kadar MCP-1 $(481,40 \pm 22,54551$ yang lebih rendah dari dosis 50 $(p=0,016)$ dan kontrol positif $(p<0,001)$ hingga sama dengan normal $(p=0,898)$. Peningkatan dosis hingga 625 tidak memberikan perbedaan kadar MCP-1 $(503,40 \pm 23,93324)$ dibandingkan dosis $50(p=0,09)$ dan $125(p=0,916)$.
Tabel 2. Hasil analisis Tukey kadar MCP-1 pada sel endotel

\begin{tabular}{ll}
\hline \multicolumn{1}{c}{ Perlakuan } & \multicolumn{1}{c}{$\begin{array}{c}\text { Kadar MCP-1 (ng/mI) Mean } \pm \\
\text { SD* }\end{array}$} \\
\hline Kontrol & $504,80 \pm 16,75410^{\mathrm{ab}}$ \\
Kontrol Leptin & $656,00 \pm 73,42683^{\mathrm{c}}$ \\
L500 Q50 & $574,40 \pm 43,72414^{\mathrm{b}}$ \\
L500 Q125 & $481,40 \pm 22,54551^{\mathrm{a}}$ \\
L500 Q625 & $503,40 \pm 23,93324^{\mathrm{ab}}$ \\
\hline
\end{tabular}

Keterangan: *) Notasi yang berbeda menunjukkan perbedaan yang signifikan $(p<0,05)$

\section{Hubungan Ekspresi NFKB dan MCP-1}

Hasil uji korelasi menunjukkan bahwa hubungan perlakuan antara aktivasi nuclear factor kappa betha (NF$\mathrm{\kappa} \beta)$ dengan kadar monocyte chemoattractant protein-1 (MCP-1) menunjukkan korelasi kuat dan signifikan ( $r=0,8$; $p=0,00)$. Hal itu menunjukkan bahwa terdapat hubungan yang signifikan antara penurunan aktivasi NF- $\beta \beta$ dengan kadar MCP-1 pada kultur sel endotel yang sebelumnya telah dipapar dengan hiperleptin. Keadaan yang sama juga terjadi pada korelasi aktivasi NF- $\kappa \beta$ dengan berbagai dosis quercetin yang menunjukkan korelasi yang sangat signifikan pula $(r=-0,803)$ dan juga korelasi kadar MCP-1 dengan berbagai perlakuan Quercetin $(50 \mu \mathrm{M}, 125 \mu \mathrm{M}$, dan $625 \mu \mathrm{M}$ ) dengan nilai korelasi $r=-0,498$.

\section{DISKUSI}

Pengukuran aktivasi NF-k $\beta$ yang dianalisis dengan One Way ANOVA dan uji Tukey dengan taraf signifikan 5\% didapatkan bahwa pemberian quercetin dengan dosis 625 $\mu \mathrm{M}$ dapat menurunkan aktivasi NF-k $\beta$ secara signifikan dibandingkan dengan kelompok kontrol leptin dan kelompok perlakuan lainnya. Dosis dari quercetin yang memberikan pengaruh maksimal pada aktivasi NF-k $\beta$ dalam penelitian ini adalah dosis quercetin $625 \mu \mathrm{M}$. Kejadian serupa juga terjadi pada penelitian terdahulu yang memberikan perlakuan quercetin pada kultur otot polos, dengan potensi Acetyl-11-Keto-6-Boswellic Acid (AKßBA) dosis (10-100 $\mu \mathrm{M})$ yang bereaksi melalui penghambatan phosporilasi C-Jun yang selanjutnya menurunkan aktifitas signaling pada AP-1 dan NF-K $\beta$. Keadaan tersebut disebabkan adanya aktifitas antiinflamatori yang ada pada quercetin yang merupakan flavonoid (antioksidan) (10).

Monocyte Chemoatractant Protein-1 (MCP-1) merupakan bagian dari molekul proatherogenik yang memicu inflamasi vaskuler kronik melalui perekrutan dan aktivasi monosit yang memainkan peran provital pada perkembangan atherosklerosis. Sel endotel, vascular smooth muscle cells (VSMC) dan leukosit ditunjukkan pada kerusakan vaskuler yang disebabkan oleh MCP-1. Dilaporkan bahwa ekspresi dari protein MCP-1 ini dapat disebabkan oleh oxidative stress, lipid inflammatory teroksidasi dan Angiotensin II. (11). Pada penelitian ini terlihat produksi MCP-1 diendotel semakin meningkat setelah pemberian leptin. Kadar MCP-1 pada kelompok $A$ $(504,80 \pm 16,75410)$ lebih rendah dibandingkan dengan kelompok B (kontrol leptin) sebesar $656,00 \pm 73,42683$. Hal tersebut terjadi kemungkinan akibat adanya peningkatan proses stress oksidatif di sel endotel yang ditengarai akibat 
adanya induksi hiperleptin yang bertindak sebagai stimulator.

Pemberian perlakuan quercetin terhadap penurunan ekspresi kadar MCP-1 pada kultur sel endotel yang dipapar dengan hiperleptin terlihat sangat signifikan. Hal itu terlihat dari data ekspresi kadar MCP-1 dengan berbagai dosis yang selanjutnya dianalisis dengan One Way ANOVA dan Tukey yang menunjukan penurunan yang signifikan dengan taraf signifikansi $5 \%(p<0,05)$ antar kelompok perlakuan quercetin. Dosis optimal dalam menurunkan ekspresi kadar MCP-1 adalah $125 \mu \mathrm{M}$ karena penurunannya terlihat berbeda secara signifikan $(p=0,00)$ dibandingkan dengan kontrol leptin, perlakuan quercetin $50 \mu \mathrm{M}$ dan $625 \mu \mathrm{M}$. Quercetin mampu menghambat phosporilasi dari berbagai reseptor growth factor dan pada jalur reactive oxygen species (ROS) serta jalur transkripsi gen. Quercetin juga merupakan anti mitogenik dan anti proliferasi (12). Quercetin memiliki peranan besar dalam menghambat aktivasi enzim-enzim kinase yang dapat menyebabkan terjadinya reaksi fosforilasi pada NF$\kappa \beta$. Quercetin juga mempunyai kemampuan dalam mencegah transkripsi gen/protein (proteomik) yang menginduksi faktor inflamasi (peradangan) seperti TNF- $\alpha$, IL-1, VCAM dan ICAM pada sel endotel (13).

Proses penghambatan pada aktivasi NF-к $\beta$ dan MCP-1 dimungkinkan terjadi melalui beberapa proses penghambatan. Proses hambatan yang pertama adalah menghambat aktivitas NADPH oksidase guna mencegah terjadinya akumulasi Reactive Oxygen Species (ROS) dan enzim yang diperlukan leptin dalam proses reduksi oksidasi (redox). Proses reaksi redox akan meningkatkan sekresi stress oksidatif dalam hal ini superoxid $\left(O^{*}\right)$ yang merupakan komponen ROS yang juga akan menghambat pengaktifan signal tranduksi di intra seluler. Quercetin berperan sebagai anti oksidan yang bertindak sebagai scavenger (13).

Quercetin yang merupakan flavonoid mampu mengikat gugus kinase, dalam hal ini adalah Mitogen Aktivated Protein Kinase pathway (MAPK). Aktivitas MAPK sebagai enzim tidak mampu meningkatkan fosforilase $c$-Jun dan inisiasi jalur Activator Protein-1 (AP-1) pada sel endotel

\section{DAFTAR PUSTAKA}

1. Weiss T and Shore S. Obesity and Asthma Direction for Research. American Journal of Respiratory and Critical Care Medicine. 2004; 169(8): 963-968.

2. World Health Organization. Obesity: Preventing and Managing the Global Epidemic. WHO Technical Report Series. 2000; 894: 1-253.

3. Dötsch Jörg, Rascher W, and Meissner U. New Insights into Leptin Resistance by Modifying Cytokine Reseptor Signal Transduction. European Journal of Endocrinology. 2005; 152(3): 333-334.

4. Bouloumie A, Marumo T, Lafontan M, and Busse R. Leptin Induces Oxidative Stress in Human Endothelial Cells. The Journal of the Federation of Americans Societies for Experimental Biology. 1999; 13(10): 1231-1238.

5. Davugnon J and Ganz P. Role of Endothelial Dysfunction in Atherosclerosis. Circulation. 2004; 109: 27-32.
$(4,9)$. Quercetin dalam hal ini mampu menghambat aktivasi NF-k $\beta$ dengan penghambatan degradasi ikB dan tidak terjadinya fosforilase. Akibatnya dimer dari NF-k $\beta$ (p50 dan p65) tidak terpelas dan selanjutnya tidak terjadi translokasi protein p50 dan protein p65 ke dalam nuklues (6). Peranan penting Quercetin dalam menghambat gen promotor pada inti sel sehingga tidak melangsungkan traskripsi protein yang bersifat proinflmatori yang disebabkan adanya stimulus dari leptin. Kemampuan Quercetin dalam menghambat promoter gen di inti sel melalui interaksi bioaktif dari Quercetin dengan gen penyandi transkripsi/translasi (nutrigenomik).

Penelitian ini menunjukkan peningkatan MCP-1 yang dapat memicu sekresi beberapa protein proinflamasi dan menimbulkan terjadinya proliferasi sel sehingga selanjutnya sel endotel mengalami formasi remodelling. Quercetin dalam hal ini mampu mencegah terekspresinya growth factor ini melalui mekanisme yang telah dibahas di atas. Hal itu dapat terjadi karena ketika protein MCP-1 disekskresikan, protein itu diduga belum melakukan interaksi sehingga kemungkinan kerjasama antar protein belum terjadi atau diduga pada tahap ini, protein tersebut masih menjalankan perannya secara sendiri-sendiri. Apabila protein kembali dikeluarkan dari sel endotel, kemungkinan terjadi proses interaksi antara MCP-1 dengan protein lain (growth factor) yang akan menstimulus mekanisme inflamatori dengan merangsang sekresi sitokin proinflamatori (TNF- $\alpha$, IL-1 $\beta$, IL-6, Eselektin, ICAM dan VCAM) dan molekul adhesi (14).

Penelitian ini membuktikan terjadi peningkatan aktivasi NF-K $\beta$ dan MCP-1 pada kultur sel HUVECs setelah diberikan leptin. Pemberian quercetin dapat menurunkan aktivasi NF-k $\beta$ pada kultur HUVECs yang dipapar dengan leptin. Quercetin dosis rendah dapat menurunkan kadar MCP-1 pada kultur HUVECs yang diinduksi paparan leptin. Penelitian lebih lanjut perlu dikaji tentang antioksidan dan senyawa flavonoid terhadap faktor inflamasi lainnya seperti Vascular Cell Adhesion Molecule-1 (VCAM-1) dan Intercelular Adhesion Molecule-1 (ICAM-1) dan beberapa protein sitokin lainnya yang diinduksi oleh paparan MCP-1 secara in vitro.

6. Middleton E Jr, Kandaswami C, and Theoharides TC The Effect of Plant Flavonoids on Mammalian Cells: Implications for Inflamation, Heart Disease and Cancer. Pharmacological Reviews. 2000; 52(4): 673 751.

7. Rosicka M, Kresek M, Moutule M, et al. Serum Ghrelin Levels in Obese Patient: There relationship to serum leptin levels and soluble leptin receptor levels. Physiology Research. 2003; 52(1):61-66.

8. Hansson GK. Mechanisms of Disease Inflammation, Artherosclerosis, and Coronary Artery Disease. The New England Journal of Medicine. 2005; 352: 16851695.

9. Ferry DR, Smith A, Malkhandi J, et al. Phase I Clinical Trial of the Flavonoid Quecertin: Pharmacokinetics and Evidence for in Vivo Tyrosine Kinase Inhibitor. Clinical Cancer Research. 1996; 2(4): 659-668.

10. Cuaz-PérolinC, Billiet L, Baugé $\mathrm{E}$, et al. Antiinflammatory and Antiatherogenic Effects of the NF-KB Inhibitor Acetyl-11-Keto- $\beta$-Boswellic Acid in LPS-Challenged ApoE-/- Mice. Asteriosclerosis, 
Thrombosis, and Vascular Biology. 2008; 28(2): 272277.

11. Lawrence GS. Implikasi Klinis Disfungsi Endotel dan Radikal Bebas. Jurnal Medika Nusantara. 2004; 25(2): 94-102.

12. Gunawan D dan Mulyani S. Ilmu Obat Alam (Farmakognosi). Jilid 1. Jakarta: Penebar Swadaya;
2004.

13. Milner JA. Molecular Targets for Bioactive Food Components. The Journal of Nutrition. 2004; 134(9): 2492S-2498S.

14. Baratawidjaja KG. Imunologi Dasar. Edisi ke-7. Jakarta: Balai Penerbit Fakultas Kedokteran Universitas Indonesia; 2006. 